\title{
GRACILIANO HERÓI: AS CONTINGÊNCIAS DO HUMANO EM CONTEXTO DE MATERIALIDADES HISTÓRICAS ADVERSAS
}

\author{
João Manuel dos Santos Cunha*
}

\begin{abstract}
By appropriating Graciliano Ramos's text Memórias do cárcere (1953), film director Nelson Pereira dos Santos makes use of a filmic transcreation (1983) to contextualize and reconfigure (both socially and culturally) the status of the narrator as memoirist in literature. As he blurs any attempt at a clear-cut hierarchization of the textualities involved, the cinematographic author promotes the resonance of two different periods in 20 ${ }^{\text {th }}$ century Brazilian history: Vargas's dictatorship (1930-1945), as lived by Graciliano Ramos himself, and that of the military régime post-1964. An interpretation of both works, considered here as being founded upon the transversal theme of the need to reformulate the past, a result of the condensation of historical time in the present which gives shape to both narratives, may be especially meaningful in the sense that it bears witness to art's capability to shed light upon human contingence in historically dark times.
\end{abstract}

KEYWORDS: literature and cinema, próprio [one's own] and alheio [another's], interdisciplinarity, transversality, Memórias do Cárcere, Graciliano Ramos, Nelson Pereira dos Santos

A literatura comparada instituiu-se, como se sabe, a partir do desejo cosmopolita de acolher a diversidade. Sua localização disciplinar em meio a uma imensa gama de textos estéticos e culturais, contemporaneamente, faz dela um campo de questionamento particularmente produtivo para a discussão de problemas que, se tomados em absoluto, dificilmente encontrarão uma formulação epistemológica consequente. Ao incorporar a qualidade de inter, posicionando-se em um lugar de intermediação de textualidades, o comparatismo implica também a ideia de reciprocidade, exercitando-se como prática eminentemente cultural. Não é noutra direção que aponta Tânia Franco Carvalhal, quando postula que a disciplina cuida não apenas das relações "entre textos e autores ou culturas, mas se ocupa com questões que decorrem do confronto entre o literário e o não literário, entre o fragmento e a totalidade, entre o similar e o diferente, entre o próprio e o alheio" (CARVALHAL, 2003, p. 11).

É relevante observar, por outro lado, que, nas últimas décadas, o comparatismo naturalmente voltou-se em grande medida para a reflexão sobre outros produtos midiáticos, como filmes, videoclipes, jogos de vídeo, possibilitando um confronto com sua tradição filológica e hermenêutica e a emergência de uma outra postura analítica,

\footnotetext{
* Professor da Universidade Federal de Pelotas (UFPel).
} 
mais produtiva e consequente, que considera a localização desse campo de estudos no amplo espaço da produção de cultura. Ou seja, o literário passa a ser visto, tanto como qualquer outro texto cultural, como objeto de uma disciplina que poderia ser nominada como "estudos textuais". Termo que compreenderia a ideia de um tipo específico de "estudos de mídia", conceitualmente inserido no que também se conhece como "estudos de intermidialidade" .

No âmbito desse campo de estudos, literatura e cinema, por exemplo, poderiam ser entendidos como mídias que se interrelacionam por meio ainda de diversos outros suportes, veículos, recursos e técnicas de representação, eis que se inscrevem na amplitude de um universo cultural no qual poderiam ser incluídos meios de produção tão diversos como a canção popular, o rádio, a imprensa escrita, a televisão, as artes visuais e, de forma geral, as mídias digitais. Nesse imbricamento de meios e produtos que envolvem questões permanentes e de amplo espectro - como representação e realidade, indústria cultural, centro e periferia, contexto histórico e político, identidade ou nação e nacionalismo - , o comparatismo oferece ainda abertura metodológica incontornável para a discussão dos processos de interferências e transferências que aí se configuram.

As relações entre literatura e cinema, mídias que ocuparam lugar de prevalência social até pouco tempo, interessam ainda hoje, em contexto de midiatização digital, para que se compreenda as operações de mutação, transformação, tradução, adaptação, citação e hibridização efetuadas não só entre elas como também delas com outros meios de produção cultural. O que não se deve perder de vista, no entanto, é o fato de que consideremos literatura e cinema quer como mídias quer como produtos culturais - , tanto o objeto literário como o fílmico para o quais buscamos produzir sentido se conformam como textualidades ${ }^{2}$. Se pensarmos assim, "intermidialidade" e "intertextualidade" seriam construções conceituais concorrentes e não excludentes; e ambas se localizariam naturalmente no espectro amplo de uma prática interdisciplinar, a qual incluiria, necessariamente, a consideração de temáticas transversais. Assim, a própria noção de interdisciplinaridade adquire hoje matizes que nos permitem pensar o literário na amplitude da produção cultural. Eis como Eduardo Coutinho postula essa condição na contemporaneidade:

Destituída de sua aura de esteticidade, a obra literária passa a ser vista como um produto da cultura e a literatura como uma prática discursiva intersubjetiva como muitas outras. $\mathrm{O}$ resultado é que a interdisciplinaridade perde também sua especificidade e a abordagem interdisciplinar generalizase. Os estudos literários tornam-se todos interdisciplinares, uma vez que passam a inscrever-se na esfera da cultura, marcada justamente pela confluência de áreas diversas do saber (COUTINHO, 2011, p. 24).

\footnotetext{
${ }^{1}$ Sobre o alcance do conceito de intermidialidade, ver: CLÜVER, Clauss. "Estudos interartes: conceitos, termos, objetivos". Literatura e Sociedade, n. 02 (EDUSP, São Paulo), 1997, p. 37-55.

${ }^{2}$ É pacífica a ideia, na teoria fílmica contemporânea, de que o texto fílmico tem autonomia de código textual, principalmente após as reflexões desenvolvidas a partir dos anos sessenta por Christian Metz: "o cinema não é uma língua, sem dúvida nenhuma, mas pode ser considerado como uma linguagem, na medida em que ordena elementos significativos no seio de combinações reguladas, diferentes daquelas praticadas pelos idiomas e que tampouco decalcam a realidade. Assim, sendo uma linguagem, permite uma escrita, isto é, o texto fílmico" (METZ, 1980, p. 338 - grifo meu). Essa reflexão repercute entre a crítica cinematográfica e a literária, gerando aplicação importante no meio dos estudos comparados que se ocupam das relações entre palavra literária e imagem fílmica, por pesquisadores como André Gaudreault (1988), Jeanne-Marie Clerc (1985, 1993), Francis Vanoye (1989) e Michel Serceau (1999).
} 
Tal constatação remete a aporte teórico-crítico fundamental para que se reflita sobre essas relações. Refiro-me à elaboração de Roland Barthes, pensada para sustentar o exercício interdisciplinar. Diz o comparatista malgré lui: "para se fazer a interdisciplinaridade, não basta tomar um 'assunto' (um tema) e convocar em torno duas ou três ciências. A interdisciplinaridade consiste em criar um objeto novo que não pertença a ninguém. O Texto é, creio eu, um desses objetos" (1988, p. 99). O que está se postulando aí é a capacidade de invenção e de construção inerente ao interdisciplinar. Assim, como entende Reinaldo Marques, caberia ao investigador "criar novos objetos de conhecimento", na pressuposição de que "os sujeitos do conhecimento sejam desinstalados de seus territórios e se disponham a atravessar suas fronteiras, adotando uma mobilidade que os habilita ao diálogo com outros sujeitos e seus referenciais teóricos" (1999, p. 63).

Os estudos comparados de literatura e cinema têm se restringido, em grande parte, ao aspecto das chamadas "adaptações fílmicas para textos literários". A proliferação dessas análises no âmbito do comparatismo tem ocasionado, no entanto, uma sensação de desconfiança quanto à relevância das questões levantadas, já que os resultados se mostram, via de regra, pouco produtivos. A causa do mal-estar estaria localizada no fato de que aos investigadores, confortavelmente instalados no terreno firme dos "estudos literários", faltaria conhecimento aprofundado do processo e dos procedimentos fílmicos, condição para que se pudessem exercer como intérpretes culturais, atuando no contexto amplo dos "estudos textuais". Com poucas exceções, o que se tem articulado é leitura cotejada de livro e filme, fulcrando a análise na identificação das diferenças e igualdades entre as duas narrativas. Dessa forma, as conclusões apontam geralmente para a ideia de que o texto fílmico não alcança o sentido pleno atribuído ao literário; ou, ainda, para a simplista constatação de possíveis "traições" perpetradas pelo diretor, por faltas ou excessos. O que faltaria a esses analistas, ainda que muitas vezes cinéfilos, seria a percepção de que toda "adaptação fílmica" para texto literário é leitura contextualizada; de que toda a transcriação de um texto verbal em imagens fílmicas é resultado da interpretação de um leitor especial: o cineasta. E que ambos os textos podem e devem ser lidos em transversalidade, como um conjunto de conexões temáticas.

Pretendendo ultrapassar fronteiras disciplinares e refletindo para além da mera comparação das diferenças e igualdades de textos narrativos formatados em diferentes mídias, é que este estudo se articula. O que se visa aqui é examinar simultaneamente textualidades produzidas em contexturas históricas diversas, enfocadas sob a temática que as atravessa: a da repressão e do autoritarismo. Amplamente, o objetivo é avançar na reflexão sobre a prática comparatista, instalando a questão no domínio da tradução intersemiótica da literatura para o cinema, por meio da discussão sobre a natureza das relações intertextuais e interculturais, vistas em enquadramento interdisciplinar. Por conta dessa visada, está implícito o fato incontornável de que toda leitura de objetos culturais e estéticos implica produção de sentido por um leitor específico: cada receptor da mensagem interpreta o texto a partir de seu horizonte de expectativas ${ }^{3}$. Posiciono-me,

\footnotetext{
${ }^{3}$ Uso a palavra "horizonte" no sentido gadameriano: "um horizonte não é uma fronteira rígida, mas algo que se desloca com a pessoa e que convida a que se continue penetrando" (GADAMER, 2003, p. 373). Para ele, na relação obra-receptor há sempre um devir entre antecipação e retrospecção, no qual o leitor oscila entre a estrutura do texto e o seu próprio imaginário; é essa fusão de horizontes de expectativa que forma um horizonte provisório, no qual o leitor produz sentido para o que lê.
} 
assim, não só como intérprete em relação, separadamente, ao texto literário de Graciliano Ramos e ao fílmico de Nelson Pereira dos Santos, mas também como "interpretante" 4 dos dois textos, analisados em conjunto.

A premissa para o exame desse corpus é a de que, ao se apropriar de Memórias do cárcere (1953), o cineasta Nelson Pereira dos Santos, por meio da transcriação fílmica de mesmo título (1983), contextualiza e reconfigura social e culturalmente o estatuto do narrador autobiográfico em literatura. Nesse deslocamento, transitando entre duas linguagens narrativas, constrói como próprio o texto alheio, inventando em ficção cinematográfica o herói que o narrador literário não quis ser no seu "relato de acontecimentos", que se fez "sem transposição fictícia" (CANDIDO, 1992, p. 89) . Embaçando qualquer possibilidade de relação hierárquica entre textualidades (BARTHES, 1992), o autor cinematográfico promove a ressonância de um período arbitrário na história social e política do país - o dos governos de Getúlio Vargas entre 1930 e 1945 - , tal como vivido e relatado pelo escritor, em um outro tempo de iniquidades - o da ditadura civil-militar pós-golpe de 1964. Com a interpretação simultânea dessas duas obras, vistas aqui como fundadas sob o tema transversal da necessidade de reelaboração do passado, resultado da condensação do tempo histórico no presente, que conforma ambas as narrativas, o que se quer é pensar sobre a possibilidade de a arte lidar com as contingências do humano em contextos de materialidades históricas adversas.

Em 1936, Graciliano Ramos trabalhava para o governo de Alagoas, como funcionário da Instrução Pública do Estado, na cidade de Maceió, em cargo que corresponderia ao que hoje se conhece como de secretário de educação. Ali chegara depois de ter sido eleito ${ }^{6}$ prefeito do município de Palmeira dos Índios, mandato ao qual renunciaria depois de dois anos (1929-1930), e de ter sido diretor da Imprensa Oficial do Estado de Alagoas, função pública da qual também se demitiu em 1931, logo após sua prisão por ter organizado grupo de resistência aos revolucionários de 1930 ${ }^{7}$. Apesar

\footnotetext{
${ }^{4}$ O conceito de "interpretante" é desenvolvido por Lawrence Venuti ao refletir sobre a produção de sentido na leitura conjunta de textos literários e fílmicos; para ele, há dois tipos de interpretadores: os "interpretantes formais", voltados à análise da correspondência estrutural entre o texto adaptado e seu hipotexto, considerando detalhes da história narrada e estilo dos narradores; e os "interpretantes temáticos", que se detêm no exame das textualidades a partir de construções como as de valor, ideologia, moral e contexto cultural. Para mais detalhes sobre o tema, ver VENUTI (2007).

${ }^{5}$ Para Antonio Candido, ainda que Memórias do cárcere se formalize como "depoimento, relato que se esforça por ser direto e desataviado, testemunho sobre o mundo da prisão", Graciliano Ramos, abandonando "as vias da criação fictícia" e se concentrando no "documento", cria um texto que "guarda os traços fundamentais da sua arte narrativa". CANDIDO, Antonio. "Os bichos do subterrâneo". In: Ficção e confissão (1992, p. 88).

${ }^{6}$ Pelo Partido Democrata, dominado na cidade pelo deputado estadual Chico Cavalcanti: "assassinaram o meu antecessor. Escolheram-me por acaso. Fui eleito, naquele velho sistema de atas falsas, os defuntos votando (eleições no Brasil anteriores a 1930), e fiquei vinte e sete meses na Prefeitura" (RAMOS apud FACIOLI, 1987, p. 41).

${ }^{7}$ A Revolução de 1930 foi o movimento armado, liderado pelos estados de Minas Gerais, Paraíba e Rio Grande do Sul, culminando com o Golpe de Estado de 1930, que depôs o Presidente da República Washington Luís em 24 de outubro, impedindo a posse do presidente eleito Júlio Prestes e pondo fim à República Velha. Em 1929, lideranças de São Paulo romperam aliança com os mineiros, conhecida como "política do café-com-leite", e indicaram o paulista Júlio Prestes como candidato à presidência da República. Em reação, o Presidente de Minas Gerais, Antônio Carlos Ribeiro de Andrada apoiou a candidatura oposicionista do gaúcho Getúlio Vargas. Em março de 1930, houve eleições para presidente da República, com a vitória do candidato governista, que era o presidente do Estado de São Paulo, Júlio Prestes, o qual não tomou posse, em virtude de golpe de estado desencadeado a partir de 3 de outubro de
} 
das evidências de compromisso e fidelidade ao governo deposto, o interventor militar de Alagoas, designado pelo "governo provisório" de Getúlio Vargas, mantém Graciliano no cargo de Diretor do Diário Oficial. É dessa época a versão definitiva de seu primeiro romance, Caetés, que será publicado, no Rio de Janeiro, em 1933, data em que é nomeado ${ }^{8}$ para o cargo de confiança de diretor da Instrução Pública e período em que termina a redação de São Bernardo ${ }^{9}$, segundo romance, que sairá em 1934.

É no contexto desses acontecimentos, portanto, que o escritor, já nacionalmente reconhecido nos meios literários, com um novo livro terminado (Angústia será publicado pela prestigiada editora José Olympio, do Rio de Janeiro, durante o período de sua prisão), é retirado de sua casa e detido no quartel do $20^{\circ}$ Batalhão Militar de Alagoas, no contexto de autoritarismo e repressão em que o país vive sob o Estado Novo getulista.

Começa aí período da vida do escritor que se constituirá na matéria de seu livro Memórias do cárcere, postumamente publicado em 1953. A narrativa foi gestada durante sua detenção em diversas prisões brasileiras, mas só vai começar a ser efetivamente escrita dez anos após e levará mais sete anos ainda para ser posta em circulação (em versão inacabada, faltando a redação do último capítulo), já durante um outro período de governo do ex-ditador Getúlio Vargas (1951-1954), agora eleito democraticamente. Minha reflexão levará em conta a necessária contextualização sóciopolítica da narrativa - os tempos de repressão e restrição das liberdades públicas e individuais, sob a égide da Lei de Segurança Nacional, então vigente no país - bem como questões específicas e concernentes à análise de textos literários: os paradigmas teóricos da representação da "memória" em literatura e o sentido da restauração do passado por meio de elaboração de linguagem. Na sequência, mas em conexão transversal entre os dois textos, analisarei a tradução fílmica de Nelson Pereira dos Santos para o texto de Graciliano, a partir também de pressupostos teóricos sobre a recuperação do passado por textos memorialistas, em exercício comparativo de leitura

1930. Getúlio Vargas assumiu a chefia do Governo Provisório em 3 de novembro de 1930, data que marca o fim da República Velha. A partir daí, esteve quinze anos no exercício do poder (de 1930 a 1934, como chefe do "Governo Provisório"; de 1934 a 1937, no Governo Constitucional, tendo sido eleito Presidente da República pela Assembleia Nacional Constituinte de 1934; de 1937 a 1945, enquanto durou o "Estado Novo", implantado após um golpe de estado). Graciliano esteve preso desde março de 1936 até fevereiro de 1937.

${ }^{8}$ Ramos teria considerado a medida governamental "um disparate administrativo, que nenhuma revolução poderia justificar". Tendo sido nomeado por um interventor federal - Capitão Afonso de Carvalho - , misto de militar e literato, permanece no cargo até março de 1936, quando é preso: na administração do órgão que cuida das escolas do Estado de Alagoas, Graciliano teria desagradado a muita gente. Toma a iniciativa de distribuir merenda, roupa, calçado e material escolar aos pobres da rede oficial; contrapõe-se ao novo interventor - professor Osvaldo Loureiro - , que queria abrir escolas sem a necessária garantia de sustentação financeira, visando aos redutos eleitorais; efetiva professoras da zona rural, ainda que sem titulação, exacerbando ódios e ressentimentos entre os docentes da capital; nega-se a prestar serviços pessoais aos figurões da ditadura; não referenda pedidos de militares para a aprovação de estudantes sem as necessárias condições de ensino-aprendizagem (FACIOLI, 1987, p. 52).

9 Tanto Caetés (1933) como São Bernardo (1934), ainda que não sejam narrativas que possam ser consideradas como "literatura engajada", ou que façam referência explícita ao governo discricionário vigente no Brasil do final dos anos vinte e no início dos trinta, são textos que buscam aplicar diretamente sobre a nossa realidade política, econômica e cultural reflexão crítica que dê conta da condição do homem brasileiro, tentando sobreviver sob a implacável estrutura social que o constringe, possibilitando, assim, ao leitor, o questionamento de instituições como a da propriedade, da família, do ensino (a escola), do poder (político), dos mecanismos de controle social, enfim, do estamento social no Brasil do início do século vinte. 
que busca investigar a relação intertextual entre as duas narrativas, vistas em seus específicos contextos sócio-político-culturais e na consideração de suas especificidades discursivas.

Preso sem acusação formal, Graciliano é levado para o quartel do $20^{\circ}$ Batalhão de Maceió e daí transferido para o porão de um navio, em companhia de criminosos comuns, com destino ao Pavilhão dos Primários, na Casa de Correção do Rio de Janeiro, local em que conviverá com outros perseguidos pela polícia política do Estado Novo e de onde será transladado ainda para a Colônia Correcional, na Ilha Grande, sendo, finalmente, reconduzido ao presídio carioca da Detenção. Durante dez meses e dez dias de cárcere, jamais foi informado sobre quais os motivos de sua prisão e nunca foi interrogado formalmente; ou seja, não houve instalação de qualquer tipo de processo ou inquérito judicial. Se não havia motivo oficial para a detenção, devem ter bastado os pretextos, os quais podem ser resumidos na constatação de sua relação problemática com o sistema administrativo-político do Palácio dos Martírios, durante o exercício dos cargos públicos por que passou, bem como sua intransigência em acolher favoritismo e nepotismo nas repartições públicas em que serviu. Além, certamente, pelo fato de ter publicado dois livros nada concernentes com os padrões reacionários e edificantes das cúpulas políticas daquele momento; de ter proibido o Hino de Alagoas nas escolas públicas, por ele considerado "uma estupidez com solecismos" (RAMOS, 1996, p. $38)^{10}$; de ser simpatizante do comunismo (embora não fosse nessa época filiado ao partido) e crítico mordaz do integralismo que se alastrava pelo país, nas rebarbas do poder ditatorial de um Estado de não-direito.

Durante o período em que esteve preso, Graciliano escreveu notas para um livro que se intitularia "Cadeia" e no qual contaria os fatos vividos desde a sua detenção em março de 1936 até a libertação em fevereiro de 1937. Esses papéis avulsos em que anotava impressões e cenas do cotidiano, descrevendo o que acontecia no ambiente das diversas prisões por que passou, aludidas em várias passagens do livro que depois veio a se chamar Memórias do cárcere, foram extraviadas, confiscadas, ou simplesmente se perderam em algum momento do cotidiano nas carceragens ${ }^{11}$.

Tivesse publicado essas anotações, sob a forma de um "memorial da cadeia", ainda que revisadas e formatadas para se transformarem em matéria de livro impresso, teríamos a narrativa testemunhal do vivido enquanto vivido. Por meio da representação literária da memória, dez anos depois, no entanto, o fato de ele resgatar a experiência,

\footnotetext{
${ }^{10}$ As afirmações de Graciliano Ramos, referenciadas neste texto, seguidas da indicação de página, a partir desta nota, são todas coletadas de Memórias do cárcere (32 ed., publicada em 1996).

${ }^{11}$ Nelson Werneck Sodré, que conviveu com Ramos, informa que "apesar das perdas das notas, tomadas no porão do navio ou na Colônia Correcional, Graciliano restabelece as coordenadas físicas e humanas da paisagem sócio-cultural em que viveu tantos meses, de tal sorte que a narração nos aparece como estabelecida sobre fatos de ontem" (SODRÉ, 1996, p. 27). No texto escrito dez anos depois, as Memórias, no entanto, o fato de ele estar escrevendo o que vive enquanto vive, aparece em diversas passagens, como naquela em que declara ao médico do presídio da Ilha Grande, com o intuito de provocá-lo: “- Levo recordações excelentes, doutor. E hei de pagar um dia a hospitalidade que os senhores me deram. / Pagar como? Exclamou a personagem. / - Contando lá fora o que existe na Ilha Grande. / - Contando? Sim, doutor, escrevendo. Ponho tudo isso no papel. / O diretor suplente recuou, esbugalhou os olhos e inquiriu, carrancudo: / - O senhor é jornalista? / - Não senhor. Faço livros. (...) / O médico enterrou-me os olhos duros, o rosto cortante cheio de sombras. Deu-me as costas e saiu resmungando: / - A culpa é desses cavalos que mandam para aqui gente que sabe escrever" (p. 158). Ou, como nesta: "Obtive lápis, papel, comecei de novo a tomar notas, embora fosse quase certo jogá-las fora. / - Ó Gaúcho, perguntei, você sabe que eu tenho interesse em ouvir as suas histórias? / - Sei. Vossa Mercê vai me botar em um livro" (p. 93).
} 
pela atualização dos fatos no presente da narrativa memorialística em primeira pessoa ${ }^{12}$, implica distanciamento temporal que coloca questões importantes para a compreensão de como o passado é enquadrado pela rememoração no presente dessa textualidade que é, ao mesmo tempo, restauração biográfica e invenção do passado. Na Poética, Aristóteles refere que a parte da alma à qual pertence a memória (mneme) é a mesma da qual nasce também a imaginação (fantasia) e, consequentemente, a representação das experiências objetivas; assim, o ofício retrospectivo de memória e imaginação se confundiriam em escritura possibilitada pelo trabalho com a linguagem. $\mathrm{Na}$ literatura de Graciliano Ramos, notadamente em São Bernardo, Angústia e Infância, esse trabalho com a linguagem, estratégica e metodicamente exercitada, mais do que expressar os fatos, visa a concretizar a própria realidade, buscando alcançar o máximo de autenticidade, ainda que com apoio em um real enganoso, fugidio e em constante mutação. O memorialismo, invocado desde seus primeiros escritos, de Caetés a Angústia, estruturados como se fossem textos de ficção mas estabelecidos como exercícios de memória que se quer objetiva, vai se desenvolver plenamente em Memórias do Cárcere, o qual, ainda que exiba "um tom de relato mais direto, nem por isso deixa de utilizar a técnica do ficcionista", que pode ser identificada na "reconstituição dos estados mentais, nos monólogos, nos diálogos", nas reconstruções dos quadros sequenciados e, principalmente, na estratégia narrativa do "uso das recorrentes repetições e reiterações" (MOURÃO, 1987, p. 454).

Vista assim, a memória recuperada pela linguagem literária, em Graciliano Ramos, acaba por revelar uma matriz complexa de sofrimento lúcido, objetivamente tecida, localizando no fazer literário um dos lugares privilegiados para a manifestação do passado e para a compreensão do vivido por meio da rememoração. Jeanne Marie Gagnebin, refletindo sobre a questão da memória, diz que a rememoração do passado significaria um investimento preciso no presente, "pois não se trata somente de não se esquecer do passado, mas também de agir sobre o presente, [que] a fidelidade ao passado, não sendo um fim em si, visa à transformação do presente" (GAGNEBIN, 2006, p. 55). Para Pierre Nora, no domínio desse entendimento, o ofício ficcional de lembrar revelaria o papel inevitável da literatura como "lugar de memória". Para ele, “esses lugares surgem e se sustentam do sentimento de que não há memória espontânea,

\footnotetext{
${ }^{12}$ A restauração dos acontecimentos no presente da textualidade literária se conforma pela conjunção de entidades narrativas fixadas em instâncias discursivas distintas: a do escritor, profissional que detém a competência da palavra escrita; a do autor, que assegura a unidade do narrado, e a do narrador, responsável pela encenação dos fatos vividos pelos personagens, inclusive pelo "herói" da narrativa. No caso do texto autobiográfico de Graciliano Ramos, essas "vozes" narrativas não só se responsabilizam pela recuperação das "memórias da cadeia", como permitem que o escritor renuncie ao seu papel de personagem-herói, ainda que narre em primeira pessoa. A necessidade de uso do pronome "eu" deixa o escritor desconfortável, como se pode observar no Capítulo 1, uma espécie de autojustificativa biográfica engendrada por Graciliano para esclarecer a natureza de sua narração dos fatos antes de começar a narrativa propriamente dita: "desgosta-me usar a primeira pessoa. Se se tratasse de ficção, bem: fala um sujeito mais ou menos imaginário; fora daí é desagradável adotar o pronomezinho irritante, embora se façam malabarismos por evitá-lo. Desculpo-me alegando que ele me facilita a narração. Além disso não desejo ultrapassar o meu tamanho ordinário" (p. 5) Para minimizar a força "heróica" do narrador em primeira pessoa do singular é que ele constantemente desliza para a primeira do plural, o que lhe permite incluir o "o outro", os companheiros do cárcere que ele quer patentear pela escrita como os heróis recuperados pela sua memória. Assim, sem afastar-se do projeto "autobiográfico", o "eu" memorialista evidencia pela escrita uma outra figura de herói: a do "eles", do conjunto dos companheiros-heróis, a quem Graciliano, no domínio da voz autoral, transformará em centro dos acontecimentos: "esgueirar-meei para os cantos obscuros, fugirei às discussões, esconder-me-ei prudente por detrás dos que merecem patentear-se" (p. 11).
} 
de que é preciso ativá-la permanentemente. E é por meio da relação pessoal com o passado que ela se revivifica, que pode ser recuperada" (NORA, 1993, p. 12).

A providência de registrar em notas escritas os fatos da cadeia e, dez anos depois, perdidas as anotações, de recuperar os fatos por meio de discurso rememorativo, dá conta, justamente, da medida de Graciliano como escritor-memorialista: "não sei por quê. Acho que o artista deve procurar dizer a verdade. Não a grande verdade, naturalmente. Pequenas verdades, essas que são nossas conhecidas" (1987, p. 127). Código estético narrativo por excelência, também o cinema coloca questões importantes para a compreensão dos mecanismos da memória no âmbito da ficção. Gilles Deleuze, ao analisar a natureza da imagem fílmica, propõe situá-la não no tradicional binário imagem-movimento, mas na síntese imagem-tempo, neologismo criado por ele para designar o caráter essencial do cinema pós-guerra. Levando em conta que a memória "é conduta de narrativa" e que ela relata o acontecido, e já que o passado "não se constitui depois do presente que ele foi, mas ao mesmo tempo", o filósofo francês diz que é preciso que o tempo "se desdobre a cada instante em presente e passado" (DELEUZE, 1990, p. 102).

Por meio dessa elaboração, a memória não estaria no sujeito, como potência a ser acionada, mas "somos nós que nos movemos em uma memória-Ser, em uma memória-mundo" (DELEUZE, 1990, p. 121). Assim, o suposto presente da narrativa fílmica não existiria, a não ser como "um passado infinitamente contraído no presente" (DELEUZE, 1990, p. 122). A "memória no cinema", então, não seria somente a encenação da memória, de recordações ou lembranças em textos fílmicos, mas a própria manifestação textual de uma memória que se narra no presente. Seria possível, assim, por via dessas premissas, considerar romances, contos, versos, filmes, desenhos, gravuras, fotografias, como constituintes e produtos de discursos que se vinculam à consciência de um passado que persiste porque pode ser resgatado por meio de estratégias de representação.

Mesmo que se deva assinalar o evidente princípio de que o trabalho artístico estabelece com a realidade uma relação "deformante e arbitrária", para usar palavras de Antonio Candido, já que "mesmo quando o intuito da representação seja o da mimesis sempre haverá uma forma de poiesis" (1985, p. 12), é possível sustentar a vinculação do texto criado ao contexto social, a partir da aproximação do trabalho da memória ao exercício de ficcionalização, o qual se construiria como princípio mobilizador da lembrança do vivido no presente da representação. Noutras palavras: a presentificação do passado pela elaboração estética tornaria possível o diálogo da ficção com uma memória que, evocando o passado, garantisse a sua manifestação no presente. Por outro lado, é preciso reconhecer, como pondera Beatriz Sarlo, que a representação estética já comprovou que é possível trabalhar o passado, enfocado não de forma global ou totalizante, mas a partir de medos, utopias, fragmentos de histórias e de memórias individuais (2002, p. 51).

Como se vê, entendendo-se a literatura e, por extensão, toda a narrativa de ficção, inclusive o cinema, como sendo alguns dos possíveis "lugares de memória" sugeridos por Pierre Nora, verifica-se que, a contrapelo de um discurso histórico que exorciza a memória, pode manifestar-se no discurso estético uma vontade do passado que, mesmo que reconheça seus limites no contexto do tempo presente, não deixa de flutuar por entre as dobras e as bordas da História. Seria, então, a memória-mundo, atualizada por meio do discurso estético, que possibilitaria a concentração do tempo pretérito em um presente inventado. Ou, como propõe Gilles Deleuze, um tempo 
passado "infinitamente contraído no presente" (1990, p. 102).

Em 1983, o cineasta Nelson Pereira dos Santos, ainda no contexto histórico do regime autoritário pós-golpe civil-militar de 1964, traduz em imagens fílmicas o texto memorialista de Graciliano Ramos ${ }^{13}$. O primeiro tratamento do roteiro ficara pronto já em 1980, mas a ideia de filmar Memórias do cárcere germinava desde os anos duros da ditadura, a partir do final dos anos sessenta, quando o filme não pôde ser feito em virtude das restrições às liberdades individuais e de criação, impostas pelo sistema de coerção montado pelos generais-presidentes ${ }^{14}$. A intenção era a de que o filme estreasse antes das eleições presidenciais programadas para 1982, mas houve problemas de produção e as filmagens começaram apenas em 1983, tendo o filme sido lançado,

\footnotetext{
${ }^{13}$ Memórias do cárcere, Brasil, 1983. Direção, adaptação e roteiro: Nelson Pereira dos Santos, a partir do romance homônimo de Graciliano Ramos. Fotografia: José Medeiros e Antonio Luiz Soares. Direção de arte: Irênio Maia. Cenografia: Adílio Athos e Emily Pirmez. Figurino: Ligia Medeiros. Montagem: Carlos Alberto Camuyrano. Som: Jorge Saldanha. Diretor de produção: José Oliosi. Produção executiva: Maria da Salete. Elenco: Carlos Vereza (Graciliano Ramos), Gloria Pires (Heloísa), Jofre Soares, José Dumont, Nildo Parente, Wilson Grey, Tonico Pereira, Ney Sant'Anna, Jorge Cherques, Jackson de Souza, Waldyr Onofre. Produções Cinematográficas Luiz Carlos Barreto/Regina Filmes/Embrafilme. Duração: 197', color. Versão restaurada, não comercial, em DVD cedido por Regina Filmes (2008) e, generosamente, pelo próprio diretor. O filme participa do Festival de Cannes em 1984, recebendo Prêmio da Crítica Internacional, FIPRESCI e acolhida calorosa da crítica. Um dos mais entusiasmados é o escritor J.-M. G. Le Clézio, que publica artigo na revista Le Nouvel Observateur, em que diz: "a força deste filme está no fato de abordar um profundo tema do nosso mundo moderno, falando desse frágil bem do qual dependem nossa felicidade e sobrevivência - a liberdade. O humanismo do cineasta brasileiro é feito de esperança, esperança de que o intelectual não será mais separado do mundo que o comove e o faz viver" (CLÉZIO, 1984, p. 6). Recebe prêmios ainda no Festival de Havana e no de Biarritz, além de diversas premiações no Brasil.

${ }^{14}$ A partir da vigência do Ato Institucional $n^{\circ} 5$, em dezembro de 1968, quatro anos depois do golpe de estado, começa o período que Elio Gaspari vai chamar de "ditadura escancarada" (GASPARI, 2002, p. 13), marcado pela cassação dos direitos políticos não só de membros do governo golpeado, mas de centenas de intelectuais, professores, escritores, jornalistas e artistas, submetidos à repressão cultural com a apreensão e queima de livros, jornais e revistas. Centenas exilam-se. Os que permanecem no país, resistem, no cotidiano difícil, ou na clandestinidade. "Escancarada, a ditadura firmou-se. A tortura foi o seu instrumento extremo de coerção e o extermínio, o último recurso da repressão política que o Ato Institucional $\mathrm{n}^{\circ} 5$ libertou das amarras da legalidade. A ditadura envergonhada foi substituída por um regime a um só tempo anárquico nos quartéis e violento nas prisões. Foram os anos de chumbo. [...] Foi o mais duro período da mais duradoura das ditaduras nacionais. [...] a tortura envenenou a conduta dos encarregados da segurança pública, desvirtuou a atividade dos militares da época, e impôs constrangimentos, limites e fantasias aos próprios governos ditatoriais" (GASPARI, 2002, p. 13). É a partir de João Baptista Figueiredo (1978-1985) que se dá, gradualmente, o início da "reabertura", com a extinção parcial dos atos contra os presos políticos e com eleições gerais, ainda que manipuladas. Em 1979, é promulgada a Lei da Anistia, que permitiu a volta dos exilados, a libertação de todos os presos políticos, a reincorporação ao serviço público dos servidores cassados, inclusive professores das universidades, e que possibilitou eleições gerais, ainda que manipuladas. Esse período de transição encerra-se em 1985, quando se elege um presidente civil, embora por meio de eleições indiretas, sem a manifestação do voto popular. Para informações detalhadas sobre o período, ver: GASPARI, 2002; 2004).
} 
comercialmente, somente em $1984^{15}$.

As centenas de personagens do livro foram concentradas em algumas dezenas na roteirização do filme, rebatizados com nomes fictícios (com exceção de Olga e Luis Carlos Prestes, do advogado Sobral Pinto e do próprio Graciliano), mas a estrutura diegética do livro está no filme, assim como a secura da linguagem, a concisão, a irreverência, a economia de recursos metalinguísticos, a valorização do humano, o respeito e a ternura pelo outro. Está, principalmente, o esforço bem sucedido de valorização da linguagem como forma de recuperar a memória do vivido, restaurando, em imagens que se articulam em rememoração, os fatos do passado para a compreensão do presente.

Para exemplificar a elaboração tradutória do código literário para o fílmico levada a termo pelo cineasta, considerando as diversas adaptações cênicas e os ajustes espaço-temporais necessários à transposição das memórias escritas para as filmadas, examinarei apenas três sequências do filme, em leitura comparada com as cenas literárias e atendendo ao essencial princípio da leitura em transverslidade. Primeiramente, aquela, ao final, em que Graciliano, ao sair da Colônia da Ilha Grande, revela ao diretor da prisão o intento de contar em livro o que presenciou; em segundo lugar, a que a ela se segue, no pavilhão dos presos; e a última - o longo plano geral, câmara fixa na embarcação que leva o prisioneiro da Ilha Grande, antes de aparecer na tela a palavra "FIM", em que se condensaria, de forma conclusiva, a ideia perseguida pelo tradutor fílmico ao longo de toda a narrativa: a da presentificação do herói que o Graciliano literário não quis ser.

Na primeira, o administrador tenta uma aproximação afável de Graciliano, na despedida burocrática, à porta do gabinete, o escritor pronto para ser escoltado para fora da Colônia Correcional - em que ambos caminham, lado a lado, em enquadramento de meio conjunto, a câmara movimentando-se em travelling para trás - , da qual transcrevo o diálogo:

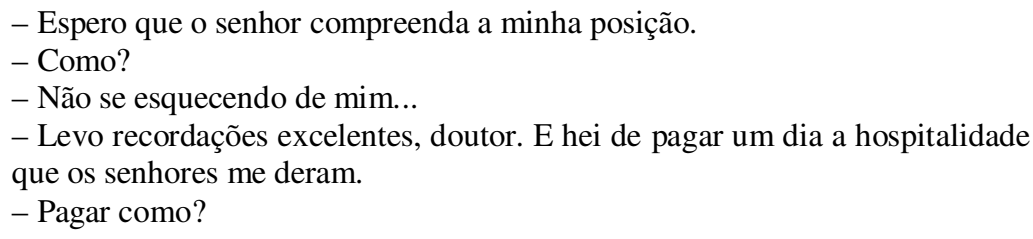

\footnotetext{
15 Nelson Pereira dos Santos já havia traduzido para o cinema outros dois textos de Graciliano Ramos, Vidas secas (1963, às vésperas do golpe militar de 1964) e um conto do livro Insônia (Um ladrão, médiametragem de 1981, dirigido enquanto esperava o início das filmagens de Memórias do cárcere. Sobre Vidas secas, pode-se dizer que o tratamento realista (neorrealista) conferido à linguagem está na origem mesma do próprio texto literário: o despojamento formal, a concisão e a objetividade contidos nos limites de uma dramaturgia sofisticada esteticamente, mas sem rebuscamentos técnicos de trucagens ilusionistas; os fatos mostrados sob a claridade crua do céu nordestino (a fotografia de Luis Carlos Barreto não utilizou filtros de luz), correspondendo ao trabalho de desdramatização perseguido pelo escritor a partir dos quadros literários no romance. Nesse filme, a questão da narratividade fílmica é resolvida com o trabalho de câmera, a qual enquadra os personagens sob o ponto de vista de um narrador em primeira pessoa, em um dos mais brilhantes exercícios de aproximação entre narrador literário e fílmico jamais realizados pelo cinema. Quanto a Um ladrão, produzido para o Sindicato de Técnicos e Artistas do Rio de Janeiro, com adaptação, roteiro e direção de Nelson, é o texto ficcional em que Graciliano Ramos retoma a figura de "Gaúcho", um dos personagens de Memórias do cárcere, aqui enfocado em ação delituosa antes de sua prisão na Ilha Grande, quando e onde vai se tornar um dos presos mais próximos de Graciliano e, nas Memórias, uma das personas mais fortes e emblemáticas da relação do escritor com os homens com quem conviveu em todos os cárceres da ditadura getulista pelos quais passou.
} 
- Contando lá fora o que existe na Ilha Grande.

- Contando?

- Sim, doutor. Escrevendo. Eu ponho tudo em um papel.

- O senhor é jornalista?

- Não, doutor. Faço livros. Eu vou escrever sobre a Colônia Correcional. Os senhores me deram um assunto magnífico...

Distanciando-se de Graciliano, o diretor da Colônia diz, em plano de meio conjunto, o qual não enquadra Graciliano: "A culpa é desses cavalos, que ficam mandando para cá gente que sabe escrever". A sequência traduz o diálogo literário do final do capítulo 30, da Terceira Parte - "Colônia correcional", praticamente na íntegra (ver transcrição na nota 6). No livro, há ainda cinco capítulos que narram os fatos finais da detenção do escritor na Ilha Grande, além de uma Quarta Parte - em que vinte e sete capítulos contam os fatos vividos na última cadeia, a Casa de Correção, no Rio de Janeiro, antes da libertação final de Graciliano - , que Nelson não aproveita na sua tradução, preferindo terminar o filme com a imagem do barco, deixando o cais da Ilha Grande, com Graciliano em liberdade.

Da forma como foi elaborada a sequência comentada acima, que antecede as cenas finais, e com a entonação decidida com que o protagonista diz ao "doutor" de suas intenções, a narrativa se organiza para que o espectador imagine a pronta realização da tarefa a que se propõe o escritor tão logo ele deixe a Ilha, e que o livro seja editado em seguida. Essa sensação é reforçada pela ênfase na determinação com que se dá a afirmação do escritor e na certeza que é conferida ao episódio no sentido de que, para o escritor, o horror experimentado nas sucessivas "cadeias" por que passou só reafirmou o sentimento de utilidade e de nobreza de seu ofício de escritor e a consequente importância do testemunho de quem, dominando a palavra escrita, pode expressar uma experiência existencial que, não sendo apenas sua, só terá sentido completo se for articulada pela linguagem no conjunto das existências dos homens-prisioneiros no cárcere da ditadura getulista. Como se sabe, em 1937, após sua libertação, o que Graciliano escreve e publica é a ficção Vidas secas, na qual, ainda que se identifiquem alguns temas - degradação do humano, autoritarismo, representação da realidade brasileira - , que serão desenvolvidos no texto memorialista, aquela é uma narrativa ficcional e não alude nem de forma indireta a situações factuais. Ainda, quando lemos, no livro, o episódio do diálogo com o "doutor", o contexto literário não nos permite entender as afirmações do narrador como sendo de total convicção. Imediatamente antes da revelação, o que Graciliano escreve é o seguinte: "chegávamos à cancela. E experimentei de chofre a necessidade imperiosa de expandir-me em uma clara ameaça. A desarrazoada tentação era tão forte que naquele instante não me ocorreu nenhuma ideia do perigo" (p. 158). O escritor, inclusive, no primeiro capítulo das Memórias, comenta os fatos anteriores ao processo da escritura que só vai acontecer em 1946:

Resolvo-me a contar, depois de muita hesitação, os casos passados há dez anos - e antes de começar, digo os motivos porque silenciei [...]. Não conservo notas: algumas que tomei foram inutilizadas, e assim, com o decorrer do tempo, ia-me parecendo cada vez mais difícil, quase impossível, redigir essa narrativa. Além disso, julgando a matéria superior às minhas forças, esperei que outros mais aptos se ocupassem dela [...]. Também me afligiu a ideia de jogar no papel criaturas vivas [...]. Repugnava-me deformálas [...] fazer do livro uma espécie de romance; mas teria eu o direito de utilizá-las em história presumivelmente verdadeira? (p. 33). 
Esse sentimento de que deveria cumprir o dever da memória, pelo outro, reaparecerá ao final do capítulo, quando comenta a necessidade de narrar em primeira pessoa, ainda que seja para esgueirar-se "para os cantos obscuros", fugindo "às discussões", para esconder-se "prudente por detrás dos que merecem patentear-se" (p. 37). Ou seja, abdicando da estatura de herói da narrativa de sua própria história para emprestar ao outro - os homens com quem conviveu em todos os cárceres da ditadura getulista por que passou - essa merecida natureza literária. Ou, ainda, tornando patente, pela invenção da memória literariamente resgatada, a sua qualidade de narrador não herói.

O que se pode concluir é que as "memórias da cadeia" só se transformaram em "memórias do cárcere" mais para o final da vida do escritor em virtude de que motivos favoráveis, de foro íntimo, superaram a hesitação constante nos dez anos anteriores ao início da incursão memorialística a um passado que, ao mesmo tempo em que precisava restaurar pela linguagem, Ramos temia não alcançar pela rememoração dos fatos, já que "coisas verdadeiras podem não ser verossímeis" (p. 36), quando narradas literariamente. De qualquer forma, a invenção narrativa do cineasta, deslocando a cena da declaração provocadora para o final do filme, sem, no entanto, colocar-se na contramão do discurso literário, realça o papel fundamental da linguagem para o resgate do vivido, posição defendida pelo articulador das imagens fílmicas até os derradeiros fotogramas do filme.

$\mathrm{Na}$ sequência seguinte, outra invenção do cineasta reitera o investimento em valorizar o relato escrito como o elo entre a experiência pessoal e a do outro - a dos companheiros das prisões - , razão definitiva para que Graciliano levasse a cabo a rememoração do horror experimentado por meio de sua recuperação como texto escrito. Como apontei anteriormente, há notícias de que as notas redigidas na Colônia se extraviaram. O narrador de Memórias do cárcere, no entanto, relata: "não resguardei os apontamentos obtidos em largos dias e meses de observação: em um momento de aperto fui obrigado a atirá-los na água”. (p. 36) Nelson Pereira dos Santos, reforçando a sintonia do escritor com os outros presos na Ilha Grande, uma das linhas mais fortemente trabalhadas na escritura de Graciliano - intransigente em sua posição de que narra, ainda que em primeira pessoa, pelos outros e não por ele - , inventa o último episódio encenado na Colônia. O cineasta assume-se integralmente como intérprete temático do texto literário para articular em texto fílmico o tema do herói.

A sequência, tecnicamente desenvolvida com economia de recursos narrativos ${ }^{16}$, explicita de forma precisa a intenção do diretor, empenhado em construir a heroicidade de seu personagem: depois que o "doutor" ouve do protagonista a informação de que colocará "tudo em um papel", segue-se cena em que, no alojamento, os soldados vasculham os pertences do escritor em busca de possíveis papéis com anotações: a defesa conjunta do manuscrito por todos os presos, cada um pegando uma folha do maço dos apontamentos entregue por Graciliano e tirando-a da vista dos soldados, converte a escritura em patrimônio da coletividade dos despossuídos da Ilha Grande. Dessa forma, reitera o narrador fílmico, dá-se a superposição entre o ofício do escritor

16 A linguagem contida do cineasta, restringindo-se ao repertório dos elementos fundamentais da estética filmica, sem recorrer a efeitos metalinguísticos por meio do uso de subcódigos cinematográficos, ou a trucagens e efeitos de montagem elaborados e antirealistas, aproxima a natureza depurada de sua linguagem ao estilo de Graciliano Ramos, sobre o qual se manifestou em entrevista publicada à época do lançamento do filme: "é um texto organizado, bonito e ao mesmo tempo simples... as palavras justas, nos lugares certos..." (apud D’AVILA, 2002, p. 35). A economia formal tanto de Graciliano quanto de Nelson poderia ser qualificada, assim, como o faz Antonio Candido ao se referir ao estilo do escritor, como uma "estética de poupança" (CANDIDO, 1992, p. 89). 
oprimido e a realidade dos oprimidos incapazes do exercício da escrita. Com o esforço em defesa da palavra passando a ser de todos, o sofrimento comum adquire sentido, transitando do espaço do individual para o da história coletiva. Ou para um coletivo de heróis, resistentes às iniquidades de um tempo em que se pode identificar "a dimensão própria do século dos autoritarismos" (CANDIDO, 1992, p. 91).

Nelson Pereira dos Santos, criando a sua história das memórias do cárcere de Graciliano e atuando com o meio de expressão que domina em nível de sofisticada escritura, acaba por interpretar transversalmente em outro contexto e por meio de diverso discurso estético o depoimento literário de uma experiência existencial que se conforma na direção do coletivo. Esse exercício de transcriação do literário ao fílmico, para resgatar a lúcida leitura que faz do episódio o crítico Ismail Xavier, dá-se "como um trajeto exemplar, apto a se erigir em metáfora para a comunhão entre intelectual e povo, fundamental para a perspectiva do filme" (XAVIER, 1984, p. 18).

Nessa mesma direção inventiva, formatam-se as últimas imagens do filme: Graciliano, atravessando o portão da Colônia Correcional, enquadramento da cena em plano geral, caminha em direção à embarcação, jogando o chapéu para o alto, o qual, em montagem por corte profundo no tempo e no espaço, acaba por se transformar, na amplitude do céu azul e luminoso e por via de exercício técnico preciso, em uma gaivota em pleno voo. O narrador fílmico, instalando sua câmara à distância, enquadra o barco afastando-se da ilha, em plano aberto fixo. Essas imagens não só ratificam a vontade do cineasta de compor o final por meio da natureza espetacular que o seu meio de expressão lhe franqueia, como oferece ao público de cinema a oportunidade de possível catarse: firmam-se imageticamente o valor da liberdade, dos direitos humanos e da dignidade. A invenção do gesto de jogar o chapéu ao ar recupera no imaginário da massa de espectadores a figura do herói de tantas outras narrativas fílmicas: a reiteração do ato final de uma jornada heroica. Durante toda essa cena, ouve-se o Hino Nacional Brasileiro na trilha sonora. O uso do poderoso subcódigo fílmico contribui, com a presentificação musical de um símbolo da Pátria, para que se instale, no imaginário do espectador, a passagem do passado recuperado pela invenção de verdade das imagens fílmico-literárias para a realidade do cotidiano de um país ainda em transição a uma democracia e a uma nação em estado de direito. Sobre essa sua opção inventiva para o capítulo da libertação que não foi escrito por Graciliano ${ }^{17}$, Nelson Pereira dos Santos afirmará: "A ideia é sair da cadeia para sempre [...], para nunca mais voltar. A cadeia das relações sociais e políticas que aprisionam o povo brasileiro. Imagine se eu vou matar quem eu escolhi para ser o meu herói. Seria dar razão à repressão" (apud SALEM, 1996, p. 361). O herói Graciliano - personagem inventado por Nelson para presentificar em imagens o narrador autobiográfico de Graciliano - adquire, assim, as proporções do mito no imaginário do telespectador mediano das salas de cinema. Em contexto que dá conta de um país em transe social, político e cultural por mais de cinquenta anos, do autoritarismo do Estado Novo getulista ao período de transição da ditadura civil-militar para um almejado estado de direito, firma-se, pela força da palavra - escrita por Graciliano e imaginada por Nelson - , a defesa intransigente da liberdade

\footnotetext{
${ }^{17}$ Silviano Santiago publicou um livro de "ficção em forma de diário", intitulado Em liberdade (1981), que abrange os primeiros dias de liberdade de Graciliano Ramos, de 14 de janeiro a 26 de março de 1937 , após deixar a Casa da Detenção, no Rio de Janeiro, vindo da Ilha Grande. Por meio de instigante exercício intertextual de pastiche, Santiago constrói narrativa na qual Graciliano é personagem e falso autor, dando conta do cotidiano do escritor logo após o período de dez meses e dez dias passados nas sucessivas prisões do Estado Novo.
} 
e a reafirmação do humano.

O que se reitera aqui, por meio da leitura transversal de livro e filme, é a ideia de que a presentificação do passado pela elaboração estética - tanto em literatura como em cinema - torna possível o diálogo da ficção com uma memória que, evocando o pretérito, garante a sua manifestação no presente. Ou, retomando Deleuze, constata-se que o esforço da rememoração permite que o passado seja "infinitamente contraído no presente" (1990, p. 102) de sua representação estética. Essa possibilidade especial de elaboração do ocorrido, resultado da condensação do tempo histórico no presente do indivíduo, diz muito sobre a possibilidade de discursos artísticos lidarem com conflitos tão esquivos, dolorosos e necessários como os provocados pela relação entre lembrar e não lembrar, entre esquecer e não esquecer, entre representar e não representar. $\mathrm{E}$ coloca, certamente, o livro-memória de Graciliano Ramos e o filme-memória de Nelson Pereira dos Santos, lidos em conjunto, como um lugar de memória (NORA, 1993).

A aproximação do literário ao fílmico possibilitou o exame dos discursos culturais a partir de onde e de quando se localizam os narradores literário e fílmico, instalados no tempo presente em que busco produzir sentido para as duas narrativas rememorativas. Por meio dessa disposição analítica, foi estabelecida rede transtextual consequente para a leitura transversal dos dois textos - locus de depoimento e testemunho, mas também de ficção e de representação, de individualidades e de História - , nos quais, ainda que se reconheça a autonomia discursiva de cada um deles, as textualidades passam a compor uma malha de sentidos pela qual se pode ler um texto no outro, e os dois como unidade significante.

\section{BIBLIOGRAFIA}

ARISTÓTELES. Da memória e da reminiscência. In: Humberto Gomes. Lisboa: Edições 70, 2001. p. 134-176.

BARTHES, Roland. Jovens pesquisadores. In: . O rumor da língua. Trad.: Mario Laranjeira. São Paulo, Brasiliense, 1988.

S/Z: uma análise da novela Sarrasine de Honoré de Balzac. Trad. Léa Novaes.

Rio de Janeiro: Nova Fronteira, 1992.

CANDIDO, Antonio. Ficção e confissão: ensaios sobre Graciliano Ramos. Rio de Janeiro: Editora 34, 1992.

. Literatura e sociedade. São Paulo: Editora Nacional, 1985.

CARVALHAL, Tânia Franco. O próprio e o alheio: ensaios de literatura comparada.

São Leopoldo: Editora da Universidade do Vale do Rio dos Sinos, 2003.

CLERC, Jeanne-Marie. Écrivains et cinéma. Paris: Klincksieck, 1985.

. Littérature et cinéma. Paris: Nathan, 1993.

CLÜVER, Clauss. Estudos interartes: conceitos, termos, objetivos. Literatura $e$ Sociedade, São Paulo-EDUSP, v. 2, p. 37-55, 1997.

COUTINHO, Eduardo Faria. Literatura comparada e interdisciplinaridade. In: CUNHA, João Manuel; OURIQUE, João Luis; NEUMANN, Gerson (orgs.). Literatura: crítica comparada. Pelotas: EDUFPel, 2011. p. 21-30.

D'AVILA, Roberto. Nelson Pereira dos Santos. In:____. Os cineastas: conversas com Roberto D'Avila. Rio de Janeiro: Bom Texto, 2002. p. 35-37. 
DELEUZE, Gilles. A imagem-tempo. Trad. Eloísa Araújo Ribeiro. São Paulo: Brasiliense, 1990.

FACIOLI, Valentim. Um homem bruto da terra: biografia intelectual. In: BOSI, Alfredo et alii (organização). Graciliano Ramos. São Paulo: Ática, 1987. p. 23-106.

GADAMER, Hans-Georg. Verdade e método: traços fundamentais de uma hermenêutica filosófica. Trad.: Paulo Meurer. 4. ed. Petrópolis: Vozes, 2003.

GAGNEBIN, Jeanne Marie. Memória, história, testemunho: o que significa elaborar o passado? In: Lembrar escrever esquecer. São Paulo: Editora 34, 2006. p. 49-57. GASPARI, Elio. A ditadura envergonhada. São Paulo: Companhia das Letras, 2002. . A ditadura escancarada. São Paulo: Companhia das Letras, 2002.

_. A ditadura derrotada. São Paulo: Companhia das Letras, 2003. . A ditadura encurralada. São Paulo: Companhia das Letras, 2004.

GAUDREAULT, André. Du littéraire au filmique: système du récit. Paris: Méridiens, 1988.

LE CLÉZIO, Jean-Marie Gustave. Cerimônia de purificação. Filme Cultura. Embrafilme, Rio de Janeiro, n. 44, p. 4-8, abr./ago. 1984.

MARQUES, Reinaldo. Literatura comparada e estudos culturais: diálogos interdisciplinares. In: CARVALHAL, Tânia (org.). Culturas, contextos e discursos: limiares críticos no comparatismo. Porto Alegre: UFRGS, 1999. p. 58-67.

METZ, Christian. Linguagem e cinema. Trad. Marilda Pereira. São Paulo: Perspectiva, 1980.

MOURÃO, Rui. Mesa-redonda: apêndice. In: BOSI, Alfredo et alii (orgs.). Graciliano Ramos. São Paulo: Ática, 1987. p. 451-454.

NORA, Pierre. Entre memória e história: a problemática dos lugares. História \& Cultura, São Paulo, n. 10, p. 7-26, dez. 1993.

RAMOS, Graciliano. Memórias do cárcere. 32 ed. Prefácio de Nelson Werneck Sodré. Rio de Janeiro: Record, 1996.

SALEM, Helena. Nelson Pereira dos Santos: o sonho possível do cinema brasileiro. Rio de Janeiro: Record, 1996.

SANTIAGO, Silviano. Em liberdade. Rio de Janeiro: Paz e Terra, 1981.

SARLO, Beatriz. A literatura na esfera pública. In: MARQUES, Reinaldo, VILELA, Lucia Helena (orgs.). Valores: arte, mercado, política. Belo Horizonte: Editora UFMG/ABRALIC, 2002. p. 37-55.

SERCEAU, Michel. L'adaptation cinématographique des textes littéraires. Liège, Belgique: Céfal, 1999.

SODRÉ, Nelson Werneck. Memórias do cárcere: Prefácio. In: RAMOS, Graciliano. Memórias do cárcere. Rio de Janeiro: Record, 1996. p. 7-30.

VANOYE, Francis. Récit écrit, récit filmique. Paris: Nathan, 1989.

VENUTI, Lawrence. Adaptation, Translation, Critique. Journal of Visual Culture, Philadelphia, USA, v. 6, n. 1, p. 25-43, 2007.

XAVIER, Ismail. Graciliano herói. Filme Cultura. Rio de Janeiro, n. 44, p. 14-18, abr./ago.1984. 